\title{
Author Correction: TGF- $\beta 1$-induced miR-503 controls cell growth and apoptosis by targeting PDCD4 in glioblastoma cells
}

\author{
Pin Guo ${ }^{1}$, Yanan $\mathrm{Yu}^{2}$, Huanting $\mathrm{Li}^{1}$, Daoxiang Zhang ${ }^{3}$, Anjing Gong ${ }^{1}$, Shifang $\mathrm{Li}^{1}$, Wei Liu ${ }^{1}$, \\ Lei Cheng ${ }^{1}$, Yongming Qiu ${ }^{4}$, Weicheng Yao ${ }^{1}$, Luo Li ${ }^{5}$ \& Yugong Feng ${ }^{1}$
}

Correction to: Scientific Reports https://doi.org/10.1038/s41598-017-11885-8, published online 14 September 2017

In the original version of this Article, all instances of “TGF- $\beta 1$ ” were incorrectly written as "TGF-âl”.

These errors have now been corrected in the HTML and PDF versions of the Article.

(i) Open Access This article is licensed under a Creative Commons Attribution 4.0 International (c) License, which permits use, sharing, adaptation, distribution and reproduction in any medium or format, as long as you give appropriate credit to the original author(s) and the source, provide a link to the Creative Commons license, and indicate if changes were made. The images or other third party material in this article are included in the article's Creative Commons license, unless indicated otherwise in a credit line to the material. If material is not included in the article's Creative Commons license and your intended use is not permitted by statutory regulation or exceeds the permitted use, you will need to obtain permission directly from the copyright holder. To view a copy of this license, visit http://creativecommons.org/licenses/by/4.0/.

(C) The Author(s) 2019

\footnotetext{
${ }^{1}$ Department of Neurosurgery, the Affiliated Hospital of Qingdao University, Qingdao, China. ${ }^{2}$ Department of Gastroenterology, the Affiliated Hospital of Qingdao University, Qingdao, China. ${ }^{3}$ Division of Oncology, Department of Internal Medicine, Washington University School of Medicine, Saint Louis, MO, 63110, USA. ${ }^{4}$ Department of Neurosurgery, South Campus, Renji Hospital, Shanghai Jiao Tong University School of Medicine, Shanghai, China. ${ }^{5}$ Department of Neurology, Qingdao Municipal Hospital, Qingdao University, Qingdao, China. Pin Guo and Yanan Yu contributed equally. Correspondence and requests for materials should be addressed to L.L. (email: liluodoctor@163.com)orY.F. (email: fengyugong001@163.com)
} 